\title{
ANTITRUST: LIMITATION ON THE GROUP BOYCOTT PER SE RULE
}

I $_{N}$ 1959 the Supreme Court unequivocally stated that group boycotts
are per se violations of the Sherman Act. ${ }^{2}$ However, a recent federal
district court decision, United States v. Insurance Board of Cleveland,
refused to follow the broad prohibition of the Supreme Court and
limited the per se rule to group boycotts exerting coercive economic
pressure. In this case, the Government brought an action under Sec-
tions I and 2 of the Sherman Act to enjoin the operation of the "mutual
rule" of the Insurance Board, a local organization consisting of inde-
pendent insurance agents. ${ }^{5}$ Under this rule, the association denied
membership to agents who did not deal exclusively with capital stock
insurance companies and required resignation of any member who did
not continue to sell only policies issued by stock insurance companies."

\footnotetext{
${ }^{2}$ Klor's, Inc. v. Broadway-Hale Stores, Inc, 359 U.S. 207 (1959).

${ }^{2} \mathrm{~A}$ group boycott is an agreement by two or more persons not to do business with other individuals or to do business with them only on discriminatory terms. HANDLER, Cases on TRADE Regulation 946-48 (1937). But the common reference to all concerted refusals to deal as "boycotts" is objectionable, since the unlawful connotations accompanying the term actually suggest the result before a determination on the merits of the validity of the refusal to deal.

${ }^{8}$ I 88 F. Supp. 949 (N.D. Ohio I960).

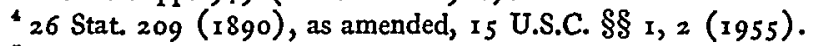

- The Board was organized and incorporated under the laws of Ohio in 1846 . The present articles of incorporation reaffirm the board's historic purpose to foster and preserve the stock ownership principle and the American agency system. In addition, the Board enters into various activities to promote and elevate the professional standards of its members and insurance agents in general. United States v. Insurance Bd., r $88 \mathrm{~F}$. Supp. 949, 95 I (N.D. Ohio I 960 ).

- The basic distinction between mutual insurance companies and stock insurance companies lies in the fact that a stock company has for its basis capital stock owned by the stockholders who own the corporation and are distinct from its policyholders, whereas a mutual company has no stockholders but only policyholders who are members of the company. Thus, in the stock companies profits are distributed to the stockholders in the form of dividends, but in the mntual companies the policyholder receives the profits by way of a "dividend" or premium allowance. However, if the mutual company fails, the policyholders might be subject to contingent liability as owners of the business, while policyholders of stock companies are not subject to such a risk. See, e.g., Moreland v. Knox, 268 S.W.2d 744 (Tex. Civ. App. 1954). See VancE, InsurancE 314-17 (1930).

There are three classes of insurance agencies: stock agencies, mutual agencies, and mixed agencies (selling both mutual and stock insurance). In Cuyahoga County, where the Insurance Board operates, there are 3,288 insurance agents, of which 775 were members of the Board, 263 are direct employees of mutual companies, and 2,250 are
} 
The Government contended that the "mutual rule" was per se unlawful under Klor's, Inc. v. Broadway-Hale Stores, Inc., ${ }^{7}$ because it operated as an agreement to boycott which tended to exclude mutual companies from representation by independent agents that were members of the board. The defendant argued, inter alia, that the per se approach was inapplicable in the present case, because the "mutual rule" operated in a noncoercive manner. Although holding that the "mutual rule" was a group boycott, the court rejected the per se approach in favor of the defendant's contention that the absence of any showing of coercion required application of the rule of reason. After investigation under the rule of reason, the Court found that the effect of this concerted refusal to sell mutual insurance was to exclude mutual companies from representation by members of the association and that, therefore, the "mutual rule" constituted an unreasonable restraint of trade. ${ }^{8}$

Early Supreme Court decisions tended to interpret literally the Sherman Act's prohibition of every contract, combination or conspiracy in restraint of trade. ${ }^{9}$ The obvious undesirability of such an approach

stock or mixed agencies who are not members of the Board. In Ohio and throughout the country most independent agents sell both types of insurance. Members of the Board gain no financial advantage by dealing exclusively with stock companies, but it is their belief that stock insurance provides a more profitable form of compensation for the agents. United States v. Insurance Bd., I 88 F. Supp. 949, 954 (N.D. Ohio 1960).

? 359 U.S. 207 (1959).

- When suit was originally brought against the Insurance Board, there were six rules of the association that were alleged to be violations of the Sherman Act. Three of the rules were eliminated by a reorganization of the Board in 1953. Upon motions for summary judgment by both parties, the court held a fourth rule to be an unreasonable restraint of trade, but refused a final determination on the two remaining board rules until trial. United States v. Insurance Bd., 144 F. Supp. 684 (N.D. Ohio I956) (proceedings on motion for summary judgment). The Government indicated it no longer desired to press its claim as to one of the rules, leaving for determination at trial the sole question whether the "mutual rule" constituted a violation of the Sherman Act.

See generally, Note, Ios U. PA. L. Rev. 977 (1957).

- "Every contract, combination in the form of trust or otherwise, or conspiracy, in restraint of trade or commerce among the several States, or with foreign nations, is declared to be illegal ..." 26 Stat. 209 (1890), as amended, I5 U.S.C. § I (1955).

Justice Peckham, who wrote the opinion in five of the first six Sherman Act decisions of the Supreme Court, Addyston Pipe \& Steel Co. v. United States, I75 U.S. 2 I I (1899); Anderson v. United States, I7I U.S. 604 (1898); Hopkins v. United States, I7 I U.S. 578 (1898); United States v. Joint-Traffic Ass'n, I7 I U.S. 505 (1898); United States v. Trans-Missouri Freight Ass'n, 166 U.S. 290 (1897), was the literalist on the Court. To him, the Sherman Act meant exactly what it said- "every" was all-inclusive; all restraints were prohibited. Once a restraint of trade was found, the conduct bringing about this restraint was absolutely prohibited. See HANDLER, ANTITRUST IN PERSPECTIVE 4-7 (1957).

The Supreme Court went so far as to suggest that a covenant not to compete by a 
soon led to the adoption of the "rule of reason," prohibiting only unreasonable restraints of trade. ${ }^{10}$ However, certain business practices were considered so inimical to competition that they were conclusively presumed to be unreasonable, regardless of any compelling business reasons offered in defense of such practices. ${ }^{11}$

Prior to the establishment of this per se doctrine, some group boycotts had been held to be reasonable restraints of trade. ${ }^{12}$ Application

sellex of a business might be condemned under the Sherman Act. United States v. TransMissouri Fright Ass'n, supra at 329 (dictum).

${ }^{10}$ To determine reasonableness, courts consider the conditions leading to the adoption of the restraint, the effect of the restraint on competition, and the intent of the participants. Or, as explained by the Supreme Court in United States v. Columbia Steel Co., 334 U.S. 495, 527 (1948): "In determining what constitutes unreasonable restraint ... we look ... to the percentage of business controlled, the strength of the remaining competition, whether the action springs from business requirements or a purpose to monopolize, the probable development of the industry, consumer demands, and other characteristics of the market."

While the rule of reason was definitely established in Standard Oil Co. v. United States, 22 I U.S. I (IgII), such an approach was advocated soon after the adoption of the Sherman Act in 1890. See Justice White's dissent in United States v. TransMissouri Freight Ass'n, I66 U.S. 290, 343 (1897). For a recent indication that the rule of reason remains the touchstone of the antitrust laws, see United States v. E. I. DuPont \& Co., 35 I U.S. 377 (1956).

${ }^{11}$ Even in the decision that established the rule of reason, the Supreme Court intimated that certain conduct was per se unlawful. Standard Oil Co. v. United States, 22 I U.S. I, 58, 65 (1911). However, the per se doctrine was not clearly enunciated by the Supreme Court until United States v. Trenton Potteries Co., 273 U.S. 392 (1927) (price fixing). But the per se doctrine has been expanded by the Court so as to include other conduct. International Salt Co. v. United States, $33^{2}$ U.S. 392 (1947) (tying agreement of patents) ; Northern Pac. Ry. v. United States, 356 U.S. I (1958) ("preferential routing" tying agreement).

There are certain definite advantages in the per se approach. It provides a degree of certainty unobtainable under the rule of reason. Such certainty is desirable from the standpoint of both industry and the government. The per se rule also diminishes the time and expense involved in judicial proceedings, since it alleviates the necessity of extensive economic investigation. However, there are certain disadvantages in this blanket approach. While the rule of reason provides little certainty, it does provide flexibility. Such flexibility is desirable when conduct is not blatantly unreasonable; the rule of reason provides the restraining party with an opportunity to justify his conduct, while under the per se rule no such consideration is permitted.

For further discussion contrasting the per se doctrine with the rule of reason, see Oppenheim, Federal Antitrust Legislation: Guideposts to a Revised National Antitrust Policy, 5o MICH. L. REv. I I39, I×48-56 (1952).

${ }_{12}$ Accord, Chicago Bd. of Trade v. United States, 246 U.S. 231 (1918); Anderson v. United States, I7I U.S. 604 ( 1898 ); Hopkins v. United States, 17 × U.S. 578 (1898).

In Chicago Bd. of Trade, supra, the Supreme Court found that a regulation of the Board prohibiting members from purchasing at the end of the business day at a price other than the closing bid actually promoted good business and did not adversely affect 
of the rule of reason enabled the Supreme Court to uphold those boycotts that promoted good business practices. After the Court decided that certain conduct was conclusively presumed to be unreasonable, it became difficult to ascertain from the opinions relating to concerted refusals to deal whether a per se rule or the rule of reason had been applied by the Court, ${ }^{13}$ but the frequent prohibitions of such conduct suggested that all such practices were per se unlawful. ${ }^{14}$ Moreover, sweeping dicta by the Supreme Court strengthened the view that all group boycotts were within the per se category. ${ }^{15}$ Whatever uncertainty remained was apparently resolved by the Klor $s^{16}$ decision. In

anyone. The Court therefore held that this rule was a reasonable restraint on trade not within the Sherman Act prohibition.

However, under the rule of reason many group boycotts were held to be an unreasonable restraint of trade. See, e.g., Binderup v. Pathe Exch., Inc,, 263 U.S. 29I (1923); Grenada Lumber Co. v. Mississippi, 217 U.S. 433 (I9ro); Loewe v. Lawlor, 208 U.S. 274 (1908); Montague \& Co. v. Lowry, 193 U.S. 38 (rg04).

${ }^{18}$ See, e.g., Associated Press v. United States, 326 U.S. I (1945), Fashion Originator's Guild, Inc. v. FTC, 312 U.S. 457 (I94I). In Fashion Originator's the Supreme Court held that it was not error for the district court to refuse to hear evidence of the reasonableness of the boycott, thus indicating approval of a per se prohibition. But the Court proceeded to investigate the boycott's effect on the market in order to be certain that there could be no justification of such conduct.

1t See Associated Press v. United States, 326 U.S. I (1945); Fashion Originator's Guild, Inc. v. FTC, 312 U.S. 457 (1941); United States v. First Nat'l Pictures, Inc., 282 U.S. 44 (I930); Paramount Famous Lasky Corp. v. United States, 282 U.S. 30 (1930); Eastern States Lumber Ass'n v. United States, 234 U.S. 600 (1914); United States v. New Orleans Ins. Exch., 148 F. Supp. 915 (E.D. La.), aff'd per curiam, 355 U.S. 22 (1957). However, the Supreme Court in a few instances did indicate that certain boycotts were not unreasonable restraints on trade. United States v. Oregon State Medical Soc'y, 343 U.S. 326 (I952); Appalachian Coals, Inc. v. United States, 288 U.S. 344 (1933).

${ }^{16}$ Times-Picayune Publishing Co. v. United States, 345 U.S. 594, 625 (1953) (dictum); United States v. Columbia Steel Co., 334 U.S. 495, 522 (1948) (dictum). A few lower courts have expressly relied on these dicta. See, e.g., United States v. New Orleans Ins. Exch., 148 F. Supp. $9{ }_{5}$ (E.D. La.), aff'd per curiam, 355 U.S. 22 (1957), United States v. Minneapolis Elec. Contractors Ass'n, 99 F. Supp. 75 (D. Minn. 1951).

${ }^{10} 359$ U.S. 207 (1957). See 57 Mich, L. REv. 1244 (1959) and 44 MinN. L. REV. 568 (1959).

Commentators have generally agreed that Klor's definitely resolved the controversy as to the status of group boycotts under the antitrust laws. According to Handler, Annual Review of Recent Antitrust Developments, 14 RECORD OF N.Y.C.B.A. 318,344 (1959): "[I]n its unanimous decision in Klor's, the Supreme Court rather bluntly and emphatically informs the lower courts that when in the past it proclaimed the per se unlawfulness of group boycotts, it meant precisely what it said. The prohibition is absolute. There are to be no exceptions, however extenuating may be the conditions generating the boycott." Oppenheim also interprets Klor's as an omnibus condemnation: "The Court [in Klor's] appears to have outlawed group boycotts absolutely. While it was previously arguable that the Court had preserved a limited area for rea- 
that case, Broadway-Hale, a large department store chain, used its economic position to "influence" manufacturers and distributors of appliances not to sell their products to a competitor. While group boycotts designed solely to eliminate competition had been previously condemned by application of the per se doctrine, ${ }^{17}$ the Supreme Court in Klor's went beyond this precedent and indicated that all group boycotts or concerted refusals to deal are per se illegal. ${ }^{18}$

Many self-imposed refusals to deal by an association such as the Insurance Board have neither an element of direct coercion on third parties nor a purpose to suppress competition. ${ }^{10}$ The existence of such self-restricting limitations prompted leading authorities writing prior to Klor's to advocate exclusion of these group boycotts from the per se censure. $^{20}$ However, the Supreme Court did not exempt self-restricting,

sonable collective refusals to deal in exceptional instances, Klor's has reduced this prospect to a mirage." Oppenheim, Selected Antitrust Developments in the Courts and FTC Dutring Past Year, I5 A.B.A. ANTITRUST Section REP. 37, 55 (1959).

However, one commentator feels that the holding in Klor's was equivocal: "What the Court actually did [in Klor's] was to avoid coming to grips with the dilemma. As a consequence it is very difficult now to know what the rule on boycotts is." Rahl, Per Se Rules and Boycotts Under the Sherman Act: Some Reflections on the Klor's Case, 45 VA. L. REv. I165, I170 (1959).

${ }^{17}$ E.g., Fashion Originator's Guild, Inc., v. FTC, 312 U.S. 457 (194x); Eastern States Lumber Ass'n v. United States, 234 U.S. 600 (1914).

${ }_{38} 35$ U.S. 207, 212 (1959).

${ }^{10}$ For example, regulations adopted by the members of a harness racing association to promote competition and to standardize the activities of that sport enable the association to attain its lawful purposes; yet such regulations could technically be defined as concerted refusals to deal with nonmembers. See United States v. United States Trotting Ass'n, Trade REg. REP. (r960 Trade Cases) If 69,76I (S.D. Ohio r960) (summary judgment), where the Government was unsuccessful in its attempt to enjoin under the Sherman Act such regulations of harness racing.

${ }^{30}$ Barber, Refusals to Deal Under the Federal Antitrust Laws, 103 U. PA. L. REv. 847 (1955); Barber, Refusals to Deal, 3 Prac. LaW. 21 (1957); Handler, Anmual Review of Recent Antitrust Developments, 12 RECORD OF N.Y.C.B.A. 411, 428-32 (1957); Kirkpatrick, Commercial Boycotts as Per Se Violations of the Sherman Act, 1o GEO. WASH. L. Rev. 302 (1942); Oppenheim, silpra, note II at II71-75. See also RESTATEMENT, TORTs $\$ 765$ (1939).

Furthermore, some lower federal courts have rejected an omnibus per se condemnation of all group boycotts. See Union Circulation Co. v. FTC, 241 F.2d 652 (2d Cir. 1957); Interborough News Co. v. Curtis Publishing Co., 127 F. Supp. 286, 299-301 (S.D.N.Y. 1954), aff'd, 225 F.2d 289 (2d Cir. 1955); Ruddy Brook Clothes, Inc. v British \& Foreign Marine Ins. Co., I95 F.2d 86 (7th Cir. 1952). Contra, United States v. Minneapolis Elec. Contractors Ass'n, 99 F. Supp. 75 (D. Minn. 195I).

The Second Circuit in the Union Circulation case, supra, stated: "When the courts ... are confronted with an alleged boycott whose deleterious effect on competition is not as apparent on its face as that of the agreements which have been held illegal per se, they may consider its actual or potential impact upon the competitive fabric of the particular industry affected." $24 \times$ F.2d at 656. 
noncoercive refusals to deal from the per se rule, and commentators have generally remained dissatisfied with such a comprehensive per se application to all group boycotts. ${ }^{21}$

In the instant case, although an agent dealing with mutual companies could not remain a member of the Insurance Board, there was no evidence that the Board exerted any pressure to prevent members from resigning in order to represent mutual companies. ${ }^{22}$ Furthermore, there was no evidence that the mutual companies had been seriously affected by operation of the "mutual rule." The only adverse effect shown was an inability of mutual companies in several instances to induce members to resign from the board in order to represent them. ${ }^{23}$ On the other hand, there was evidence that members did not suffer any economic loss by resignation, but in many respects improved their competitive position, since after resignation they could retain their agency agreements with stock companies and acquire similar arrangements with mutual companies. Thus, the instant case presented the type of refusal to deal that had led many authorities to reject a blanket per se rule for group boycotts. Following the approach recommended by these commentators, the district court limited the broad per se condemnation of group boycotts in Klor's to the facts in that case. Finding no similar instance of "coercive economic pressure" in the present case, the court applied the rule of reason to determine whether the "mutual rule" constituted an unreasonable restraint of trade.

The instant case indicates the inadvisability of universal condemnation of group boycotts, as stated in Klor's. ${ }^{24}$ Such a mechanistic approach

\footnotetext{
${ }^{21}$ See Oppenheim, supra note 16 ; Rahl, supra note 16 . It is difficult to determine whether Handler approves or disapproves of the broad condemnation of Klor's. Handler, supra note 16 , at 347 .

Another district court has also refused to follow the Supreme Court's mandate in Klor's. United States v. United States Trotting Ass'n, Trade REg. REP. (Ig60 Trade Cases) I 69,76r (S.D. Ohio Ig60).

${ }^{22}$ The evidence tended to show that board agents could accept representation of mutual companies on a trial basis and still retain membership on the board pending a final determination whether to accept mutual representation permanently. After such a trial, some agents relinquished their membership in order to represent mutual companies, while others decided not to represent mutual companies and retained their membership in the board. United States v. Insurance Bd., I 88 F. Supp. 949, 953 (N.D. Ohio I960).

${ }^{23}$ However, there was evidence of members of the Board resigning in order to represent mutual companies. In addition, field agents of mutual companies seeking new agencies also met with rejections from non-board members. Nor did it appear that the number of rejections received from the board members was proportionately greater than rejections from non-board agents. United States v. Insurance Bd., I88 F. Supp. 949, 953 (N.D. Ohio I960).

${ }^{26} \mathrm{~J}$ ust as a comprehensive per se rule has been recognized as undesirable as to all
} 
would inhibit some socially and economically desirable business activities. $^{25}$ In addition, the general per se prohibition proposed by the Government in the present case would infringe on the right of businessmen to adopt reasonable restrictions for the lawful purpose of promoting their economic well-being. Such restrictions, as long. as they do not materially affect nonmembers, should not be invalidated under the antitrust laws. ${ }^{26}$ However, from this approach, the holding in the present case that the "mutual rule" constituted an unreasonable restraint of trade is questionable, since this provision enabled the Insurance Board to further its legitimate business aspirations with only a slight effect on those outside the association. ${ }^{27}$

By the adoption of a "coercion" test, the present case apparently contradicts the absolute prohibitions of group boycotts laid down by the Supreme Court in Klor's. ${ }^{28}$ While the "coercion" test has often been advocated by commentators, ${ }^{29}$ this solution is not entirely satisfactory;

tying agreemeuts, it seems that an all-inclusive rule for group boycotts is equally inadvisable. See Northern Pac. Ry. v. United States, 356 U.S. I (1958) (limited per se rule applied to tying agreement). For a comparison of the per se-group boycott approach with the more limited per se-tying agreement rule, see Rahl, saspra note $2 \mathrm{I}$, at II 73.

${ }_{25}$ See generally Oppenheim, supra note II, at II 7 I-75.

${ }^{20}$ The Supreme Court in Eastern States Lumber Ass'n v. United States, 234 U.S. 600, 609-10 (I9I4), states: "[I]n its proper construction the [Sherman] act was not intended to reach normal and usual contracts incident to lawful purposes and intended to further legitimate trade...."

${ }^{27}$ Moreover, the Board renders valuable services to the community, such as offering educational courses in insurance. The Board also assists the State Superintendent of Insurance in his enforcement of insurance regulations, and advocates and opposes various legislation affecting insurance business. United States v. Insurance Bd., 188 F. Supp. 949, 95 I (N.D. Ohio 1960).

${ }_{28}$ See note 16 supra. In many respects Eastern States Lumber Ass'n v. United States, 234 U.S. 600 (1914), is similar to the instant case. In that case an association of retail lumber dealers sent to its members a "blacklist" of those wholesale dealers that had sold directly to consumers. The Supreme Court found that the obvious implications of such a list constitute a concerted refusal to deal with the listed wholesalers, and in language indicative of a per se approach the Court enjoined the sending of such a list to members of the association. Although blacklisting by itself may be no more "coercive" than the operation of the "mutual rule", other factors in that case seem to justify the per se approach and distinguish the case from the Instrance $B d$. decision. In Eastern Lumber the association boycotted competitors for the sole purpose of suppressing that competition. The boycott in the instant case was not of competitors, nor was there any showing that the Board's motive in applying the "mutual rule" was to suppress competition.

${ }^{20}$ See, e.g., ATT'Y Gen. NAT'I COMm. ANTITRUST REP. $x 32$ (1955); Barber, supta note 20, at 875-79; Barber, Refusals to Deal, 3 Prac. Law. 2 I (1957); Kirkpatrick, supra note 20; Oppenheim, supra note II, at I17x-75; Rahl, supra note I6. 
coercion may appear in many different forms and is not always readily ascertainable. ${ }^{30}$ Nevertheless, by differentiating those group boycotts that should be dealt with summarily from those that should be further analyzed in the context of their operation, the "coercion" approach provides a degree of flexibility unobtainable under strict per se doctrine.

${ }^{30}$ While the coercive element in Klor's was blatant, in many situations it would not be so obvious. See, e.g., Ruddy Brook Clothes, Inc. v. British \& Foreign Marine Ins. Co., I95 F.2d 86 (7th Cir. I952) (bad risk insurance list sent to insurance companies throughout the country). Thus, the "coercion" test will require in many instances investigation into the nature of the industry in order to uncover any possible coercive factors, and such investigation defeats in part the utility of the per se treatment. But most commentators have accepted the "coercion" test as a workable and preferable alternative to an all-inclusive per se rule. See authorities cited in note 29 supra. However, Handler has been outspoken against the adoption of a "coercion" test: "The only thing that seems reasonably clear to me is that it is not particularly fruitful to analyze the problem in terms of whether the boycott has a coercive effect on third parties outside the group. A group boycott by its very nature involves coercion and inescapably has an impact on the outsiders against whom it is directed. Such an approach introduces no real flexibility into the standards of legality governing joint refusals to deal." Handler, Annual Review of Recent Antitrust Developments, 12 RECORD OF N.Y.C.B.A. $411,431-32$ (1957). 